\title{
Callus Induction from Leaf and Stem Explants of Selected Turkish Genotypes of Common Bean
}

\section{Asli Küçükrecep and Dilek Tekdal*}

Department of Biotechnology, Faculty of Science and Letters, Mersin University, Mersin, Turkey

*Corresponding Author: Dilek Tekdal, Department of Biotechnology, Faculty of Science and Letters, Mersin University, Mersin, Turkey.
Received: September 21, 2021

Published: October 05, 2021

(C) All rights are reserved by Asli Küçükrecep and Dilek Tekdal.

\begin{abstract}
Common bean (Phaseolus vulgaris L.), a species belonging to the family Fabaceae, is one of the most critical legumes consumed and grown globally. Common bean ranks first among grain legumes in terms of cultivation area and production in the world. However, the bean is recalcitrant, making obtaining this plant via in vitro culture techniques a challenge. Due to changing climatic factors and drought conditions that may happen in the future, it is essential to produce plants that make up human food in vitro conditions. With this goal, the effect of different concentrations of 2,4-D and Kinetin and their possible combinations on callus induction in leaf and stem explants of three-bean genotypes (Bitlis117, Göynük, and Önceler) were evaluated. It aimed to determine the best medium that promotes callus formation in different bean genotypes and tissue types. Callogenesis was successfully promoted from leaf and stem explants of all three genotypes tested. The highest callus ratio was obtained from stem explants of Bitlis117 cultured on the MS medium, including 2,4-D (0.5 $\left.\mathrm{mg} \mathrm{L}^{-1}\right)$ and Kinetin $\left(2.0 \mathrm{mg} \mathrm{L}^{-1}\right)$.
\end{abstract}

Keywords: In vitro Culture; Leaf; Mersin; Phaseolus vulgaris L.; Stem

\section{Introduction}

Edible legumes are protein-rich plants and are rich in various vitamins, phosphorus, potassium, and iron. Considering that malnutrition and hunger are significant problems for the world population, legumes are an essential food source for the whole world due to their protein content [1]. In addition, thanks to the symbiotic relationship they establish with the rhizobium bacteria attached to their roots, they contribute to the soil's enrichment by binding the air's free nitrogen to the soil [2]. Common bean (Phaseolus vulgaris L.) is one of the main legumes for Latin America, Asia, and Africa and is included in the Fabaceae family. Phaseolus vulgaris $\mathrm{L}$. is also an economically important crop $[3,4]$. According to the Food and Agriculture Organization (FAO) (2019), Turkey ranks 11th in dry bean yield in the world, 21st in production amount, and 38th in production areas [5]. Despite its consumption potential, its sensitivity to various pathogens and lack of drought tolerance dramatically reduce yield and adversely affect production [6-8]. Tissue culture, one of the methods used for plant regeneration, provides fast and easy reproduction and allows the development of new species with the potential to create genetic variations. It can expand the options available to growers and offer new approaches to meet the need [9-11]. Common bean is known to be a recalcitrant species in vitro regeneration. Although it is difficult to obtain a positive result by micropropagation, the responses received show extremely high variability. Although regeneration studies are conducted within the framework of specific protocols in the literature, a stable and reproducible in vitro culture system has not been developed yet, and it continues to be a significant problem [12]. In general, it is 
preferred that the protocols to be created for this purpose are genotype-specific [13]. However, the response of the genotype can also be determined by the source of the explant, various growing conditions, and the condition of the explant [12]. In some studies, different meristematic tissues, cotyledons, petiole, and calli produced from embryos were used as explant sources. Low regeneration poses a problem in these studies as well [4,13-20]. Callus, an unorganized cell mass, can be obtained by taking an explant source isolated from the plant into the appropriate nutrient medium [21]. Some studies have shown that with the addition of different auxin and cytokinin concentrations to the nutrient medium used, callus cells can continue to divide and turn into organized roots and shoots [22]. To ensure the regeneration of calli obtained by in vitro techniques to obtain new plants, the prerequisite is determining the optimal explant source and nutrient medium that gives a high callus induction rate. The study aimed to determine an optimal nutrient medium and explant source that provides high callus induction and optimize a reproducible system for the three selected $P$. vulgaris L. genotypes (Bitlis117, Göynük, and Önceler).

\section{Materials and Methods}

In this study, three-bean genotypes Bitlis-117, Önceler, Göynük were used. Bitlis117 is a local bean line, and Bitlis117 was selfed pollinated three times, and made homozygously. Göynük and Önceler are the varieties registered by the Transitional Zone Agricultural Research Institute in 1998. The bean lines were arranged in randomized complete blocks. Seeds of the varieties (Figure 1) were planted in $13 \mathrm{~cm}$ plastic pots containing 3 liters of soil mixture (1 peat: 1 perlite: 1 sand: 1 field soil) at the experimental area of Mersin University, Mersin, Turkey, in 2021. Plants were grown in the greenhouse under the existing photoperiods in Mersin. The growing plants were fertilized weekly with various fertilizers.

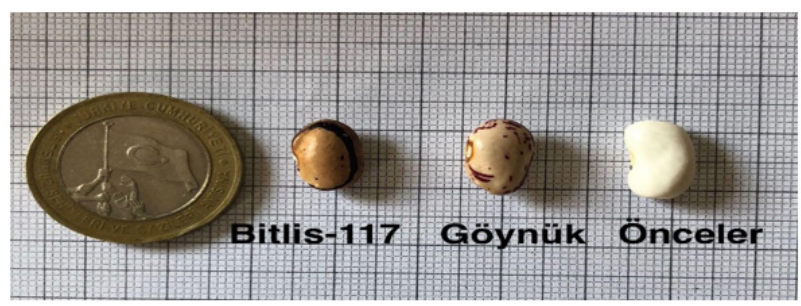

Figure 1: The view of the seeds used in the present study.
Leaf and stem samples were collected 30 days after planting. Explants were washed with running tap water, and surface sterilization was conducted by soaking for $1 \mathrm{~min}$ in $70 \%$ ethanol, then for 10 min in $20 \%$ sodium hypochlorite with two drops of Tween-20 solution and rinsed three times with sterile distilled water. Stems and leaves were cut into 5 to $10 \mathrm{~mm}$-long segments and removed, and the tissues were used for culture. Explants were placed into $100 \times 15 \mathrm{~mm}$ disposable Petri dishes containing $25 \mathrm{ml}$ of nutrient medium solidified with $0.7 \%$ agar. The nutrient medium contained the salts and vitamins of MS [23]. Each medium was used at 3\% concentrations of sucrose. The $\mathrm{pH}$ of these media was adjusted to 5.7 with $\mathrm{HCl}$ or $\mathrm{KOH}$ before autoclaving at $121^{\circ} \mathrm{C}$ for $15 \mathrm{~min}$. Various concentrations of Kinetin $(0,0.5,1.0,2.0,2.5,3.0,3.5$, and 4.0 $\left.\mathrm{mg} \mathrm{L}^{-1}\right)$ and 2,4-D $\left(0,0.5,1.0,2.0\right.$, and $\left.4.0 \mathrm{mg} \mathrm{L}^{-1}\right)$ and different combinations were tested. Tissue cultures were incubated for two weeks at $26^{\circ} \mathrm{C}$ in darkness.

\section{Results and Discussion}

Seeds of three genotypes (Bitlis117, Göynük, and Önceler) were sown in the greenhouse, and seed germination occurred in all tested genotypes successfully. Leaf and stem explants were isolated from each genotype and were cultured on the media, including different combinations of auxin (2,4-D) and cytokinin (Kinetin) for callus induction.

Stem and leaf explants cultured on MS medium free from growth regulators were turned to brown after ten days of culturing and died. Samples cultures on the media, including kinetin and 2,4-expanded and increased in size during the first two weeks in culture. Green and nodular calluses were developed from the explants. Most calli induced from stem and leaf cultures on media supplemented with $2 \mathrm{mg} \mathrm{L}^{-1}$ kinetin and $0.5 \mathrm{mg} \mathrm{L}^{-1} 2,4-\mathrm{D}$, and the calli generated on this media was very compact. According to the microscope images of the calli developing from the leaf (Figure 2) and stem (Figure 3), the calli primarily developed at the ends of the cultured samples and had a green color. This result indicates that the nutrition media with the inclusion at the appropriate concentration of kinetin and 2,4-D have a role in the callus induction from leaf and stem explants callus of these three-bean lines.

Callus induction at selected common bean cultivars from leaf and stem explants has not been reported previously in legumes. The importance of the genotypic response in tissue culture has been recognized in grain legumes $[18,24,25]$. In our study, callus 


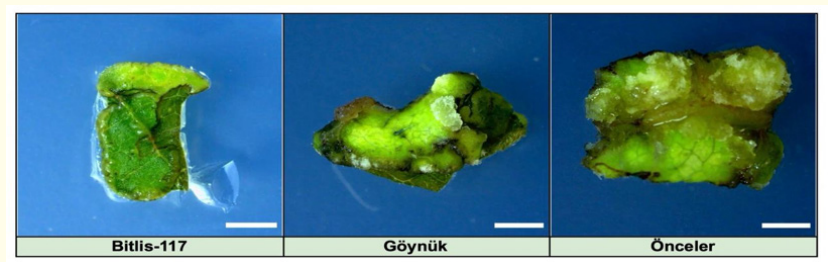

Figure 2: Stereo microscope images (Olympus SZ61, Japan) of callus growing from leaf cultured in MS medium including $2 \mathrm{mg}$ $\mathrm{L}^{-1}$ kinetin and $0.5 \mathrm{mg} \mathrm{L}^{-1} 2,4-\mathrm{D}$ (magnification: $1.2 \mathrm{x}$; scale bar $200 \mu \mathrm{m})$.

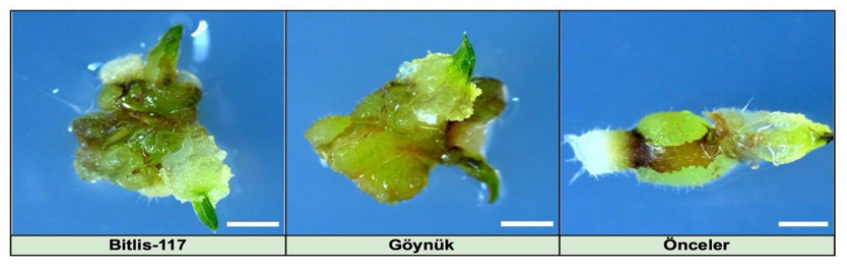

Figure 3: Stereo microscope images (Olympus SZ61, Japan) of callus growing from stem cultured in MS medium including 2 mg L ${ }^{-1}$ kinetin and $0.5 \mathrm{mg} \mathrm{L}^{-1} 2,4-\mathrm{D}$ (magnification: 1.2x; scale bar $200 \mu \mathrm{m})$.

induced both leaf and stem explants from all three common bea lines successfully. The rate of induction of the callus observed wa related to the used nutrition media since that callus was not ir duced in all media tested. The low rate of induction from explant cultured on the media containing a high concentration of kineti and 2,4-D relatively to optimum media may be due to toxic effect of the high concentration of plant growth regulators. The best ca lus response from leaf and stem explants was obtained from th media, including $2 \mathrm{mg} \mathrm{L}^{-1}$ kinetin and $0.5 \mathrm{mg} \mathrm{L}^{-1} 2,4-\mathrm{D}$. Callus initiation was not increased with the increase of kinetin and 2,4-D but was not decreased with the decrease of concentrations of kinetin and 2,4-D. Exclusively, the combination of suitable amounts of plant growth regulators resulted in successful callus induction on stem and leaf explants. Although the highest rate of callus develor ment occurred on media including $2 \mathrm{mg} \mathrm{L}^{-1}$ kinetin and $0.5 \mathrm{mg} \mathrm{L}$
2,4-D, callus formation was observed from samples cultured on the media, including the different concentrations of kinetin and 2,4-D. In terms of callus formation, no significant difference was observed among the selected explants. However, a relatively higher rate of callus formation was observed in stem explants.

\section{Conclusion}

From the data obtained from this study, essential conclusions were drawn. First, selected suitable media is a critical parameter in callus formation in tissue culture. MS medium including $2 \mathrm{mg} \mathrm{L}^{-1}$ kinetin and $0.5 \mathrm{mg} \mathrm{L}^{-1} 2,4$-D is the most successful medium for callus induction in P. vulgaris L. As a result, it may serve as the foundation for micropropagation procedure for $P$. vulgaris. The research results discussed here contribute to further studies on in vitro regeneration of common beans. Understanding the role of growth regulators for selective bean genotypes has greatly aided bean regeneration under controlled conditions.

\section{Conflict of Interest}

There is no financial interest to report and no conflict of interest.

\section{Bibliography}

1. Şehirali S. "Yemeklik Tane Baklagiller". Ankara ÜniversitesiZir aatFakültesiYayınları: DersKitabı: 314, Ankara, (1988).

2. Elçi, Ş., et al. "Tarlabitkileri”. Ankara ÜniversitesiZiraatFakülte siYayınları: 1385, Ankara (1994).

3. Delgado-Sanchez., et al. "An organogenic plant regeneration system for common bean (Phaseolus vulgaris L.)". Plant Science 170 (2006): 822-827.

4. Varisai Mohamed., et al. "Organogenesis of Phaseolus angularis L.: high efficiency of adventitious shoot regeneration from etiolated seedlings in the presence of N6-benzylaminopurine and thidiazuron". Plant Cell Tissue and Organ Culture 86 (2006): 187-199.

5. FAO. "The State of Food Security and Nutrition in the World 2019" (2019).

6. Haterlein AJ. “Crop Water Relations”. Wiley (1983): 157-185.

7. Aragão., et al. "Inheritance of foreign genes in transgenic bean (Phaseolus vulgaris L.) co-transformed via particle bombardment". Theoretical and Applied Genetics 93 (1996): 142-150. 
8. Cruz de Carvalho., et al. "Comparison of the physiological responses of Phaseolus and Vigna cultivars when submitted to drought conditions". Environmental and Experimental Botany 40 (1998): 197-207.

9. Larkin PJ and WR Scowcroft. "Somaclonal variation-a novel source of variability from cell cultures for plant improvement". Theoretical Applied Genetics 60 (1981): 197-214.

10. Evans DA and JE Bravo. "Phenotypic and genotypic stability of tissue culture plants". Springer, Dordrecht (1986).

11. Bajaj YPS. Biotechnology in agriculture and forestry II: Somaclonal variation in crop improvement". Springer-Verlag. Germany (1990).

12. Velcheva M and Bhowmik G. "Biotechnology as a useful tool i: common bean (Phaseolus vulgaris L) improvement". Euphytic 131 (2003): 189-200.

13. Hnatuszko-Konka, K. et al. "Phaseolus vulgaris". Recalcitrant Potential 32 (2014): 1205-1215.

14. Kartha K., et al. "Plant regeneration from meristems of grain legumes: soybean, cowpea, peanut, chickpea, and bean". Canadian Journal of Botany 59 (1981): 1671-1679.

15. Mariotti, D., et al. "Genetic transformation of grain legumes: Phaseolus vulgaris L. and P. coccineus L". Journal of Genetics and Breeding 43 (1989): 77-82.

16. McClean P and KF Grafton. "Regeneration of dry bean (Phaseolus vulgaris L.) via organogenesis". Plant Science 60 (1989): 117-122.

17. Franklin CI., et al. "Plant regeneration from seedling explants of green bean (Phaseolus vulgaris L.) via organogenesis". Plant Cell Tissue Organ Culture 24 (1991): 199-206.

18. Malik KA and Saxena PK. "Regeneration in Phaseolus vulgaris L.: Promotive role of N6-benzylaminopurine in cultures from juvenile leaves". Planta 184 (1991): 148-150.

19. Martins IS and Sondahl MR. "Multiple shoot formation from shoot apex cultures of Phaseolus vulgaris L". Journal of Plant Physiology115 (1984): 205-208.
20. Zambre MA., et al. "Plant regeneration from embryo-derived callus in Phaseolus vulgaris L. (common bean) and P. acutifolius A. Gray (tepary bean)”. Plant Cell Reports 17 (1998): 626630 .

21. Gönülşen N. "Bitki dokukültürleriveuygulamaalanları". EgeTarımsalAraştırmaEnstitüsü. Yayın No.78 (1987).

22. Hartmann HT and Kester DE. "Plant Propagation: Principles and Practices". Englewood Cliffs: Prentice-Hall. (1975).

23. Murashige T and Skoog F. "A revised medium for rapid growth and bioassays with tobacco tissue cultures". Physiologia Plantarum 15 (1962): 473-497.

24. Barwale UB., et al. "Plant regeneration from callus cultures of several soybean genotypes via embryogenesis and organogenesis". Planta 167 (1986): 473-481.

25. Parrott WA., et al. "Effect of genotype on somatic embryogenesis from immature cotyledons of soybean". Plant Cell Tissue Organ Culture 16 (1986): 15-21.

\section{Volume 5 Issue 11 November 2021 \\ (C) All rights are reserved by Asli Küçükrecep and Dilek Tekdal.}

